\title{
Ignorance of Political Correctness on Joko Widodo's Political Rhetoric in the 2019 Presidential Election Campaign: a Pragmatic Study
}

\author{
Ahmad Sirulhaq* \\ Indonesian Language Department \\ Universitas Mataram \\ Indonesia \\ ahmad_haq@unram.ac.id \\ Mochamad Asyhar \\ Indonesian Language Department \\ Universitas Mataram \\ Indonesia
}

\author{
Saharuddin Saharuddin \\ Indonesian Language Department \\ Universitas Mataram \\ Indonesia \\ Samsinas Jafar Sukri \\ Indonesian Language Department \\ Universitas Mataram \\ Indonesia
}

\begin{abstract}
The 2019 Presidential Election is one of the general elections considered as the noisiest so far. This is because of the increasing strength of polarization that occurs between groups of people that are fighting due to limited choices of candidates led by applying of presidential threshold that reaches 20 percent. In addition, the rampant dynamics that have occurred in social media have increasingly sharpened the confrontation between such groups. One of the interesting phenomena in the 2019 Presidential Election is the use of political rhetoric that is related to the ignorance of political correctness that sometimes reflects tastes that are beyond the general principle that can be socially or culturally tolerated. This rhetoric was used not only by elites of political parties but also by both candidates of the Presidential Election of 2019, namely Joko Widodo and Prabowo Subianto. Because of a limited space, this article just focuses on one candidate only, namely Joko Widodo. Therefore, this article tries to shed a light on such issue, that can be formulated into two purposes: (1) describing the rhetoric that is related to an ignorance of "political correctness" used by the presidential candidate number 01 ; (2) describing a conversational implicature in the use of Joko Widodo's rhetoric related to the ignorance of the political correctness. To address the problems, researchers used documentation methods to collect data and applied a pragmatic approach to analyze them, especially those related to conversational implicatures.
\end{abstract}

Keywords - political correctness, rhetoric, precedential election

\section{INTRODUCTION}

Research related to political correctness has been carried out by many experts, covering a variety of scientific backgrounds and approaches. Among these are the humanistic psychological approach [1], the comparative approach [2], the intercultural communication approach [3], discourse approach [4], historiography and anthropology approaches [5], the intercultural communication approach [3]; discourse approach [4], historiographic and anthropological approaches [5] cognitive [6], etc.

However, it is rarely found a research that is related to political correctness which involves a scientific discipline of language, in this case pragmatics approaches. At least, this research is rarely found in Indonesia. In fact, if we look closely, political correctness is an expression of language related to rhetoric. At the same time, the study of political correctness has attracted a lot of scientists in the world with a variety of topics.

Bylund \& Jonas [7], for example, examine the dangers that can occur related to the binary opposition between post-politics and proper-politics in political correctness. Apart from that, looking at the negative aspects of the political correctness, Al-Rawi [8], compared to Ivón Cepeda-Mayorga in Philosophies [9], tries to look at both aspects at once, namely the good and negative sides. According to him, the advantage of political correctness is "preventing individuals from danger, violation, and discrimination"; while its weakness is "ideological and political intervention because it will be difficult to separate cultural/political ideology from a language".

In general, the ignorance of political correctness in linguistic expressions is usually used to attack political opponents, although this is not always the case. One of the in-depth studies in the context related to this has been conducted by [5]. By using a historiography and anthropology approach, Stade instead of giving conventional conclusions related to the concept, he precisely concluded that political correctness has a connection with the rise of fascism throughout the world today and the rejection of political incorrectness is both indicative and instrumental in the process.

This fact is not excessive, it is shown by the fact that some politicians reject the use of "political correctness" to achieve certain political goals. In the world, one of the politicians who successfully used "anti-political correctness" to campaign in the presidential election was Donald Trump. In a research conducted by Conway [10], there is evidence that norms designed to increase the overall amount of positive communication can actually bring about a boomerang. Conversely, politicians can increase the amount of support by using very negative language, which explicitly violates norms or "anti-political correctness". 
In this regard, Trump, who often violates the norms in communication, is seen as getting more political advantage than Clinton who tends to maintain the norms in communication. These patterns were also used by Bush at the beginning of the military campaign against Iraq in 2003. Желтовський [11] shows that in order to assure internal and international immunity, Bush applied rhetoric based on principles called "political correctness. ", Or rather a violation of "political correctness" or "antipolitical correctness".

In Indonesia, this study related to political correctness has not attracted much attention from researchers, especially in the political context. In fact, the uses of rhetoric which is related to "political correctness" are very widely used in Indonesia in the dynamics of contemporary politics, especially in the 2019 presidential election. In connection with that, the issues raised in this article are: (1) how is the rhetoric related to the ignorance of "political" correctness "used by presidential candidate Joko Wododo?; (2) is the conversational implicature in the use of rhetoric related to ignoring Joko Widodo's "political correctness"?

\section{CONCEPTUAL FRAMEWORK}

Conceptually, "political correctness" is a phrase or term that refers to the use of a particular language by a person (or politician), which is strived to have no negative content or does not offend a particular person or group or, in the Indonesian context, does not offend SARA. This term began to emerge around the end of the 20th century, especially in relation to the dynamics of liberal democracy in Western Europe and America, including in Asian and Eastern countries [12]. The Oxford Dictionary (website) defines this term as "the avoidance of forms of expression or actions that are perceived to exclude, marginalize, or insult groups of people who are socially disadvantaged or discriminated against".

Considering the rhetoric associated with "political correctness" presupposes to discredit other groups, which are implicitly or explicitly expressed in the use of language, the implicatures of this conversation are important to note. Thus, the meaning of the utterance can be interpreted more precisely.

The beginning of pragmatic studies related to implicature was put forward by one of the famous philosophers, Grice, in 1975. The basic assumption of this concept is, one often says something more than what is stated in his words; in other words, there is a surplus of meaning behind the statement [13].

In everyday life, a person often uses implicatures without or with certain goals. When parents say "it's dark already" to their children, this can take on a variety of things, apart from just information that "day is dark". Other meanings that could arise as a result of this statement could have been a command to his child that 'no longer playing outside'; 'Close the doors and windows of the house'; 'Get ready to go to the mosque to pray' and so on. Here, various possible surpluses are arising from the statement "it's dark already" earlier. It is this surplus of meaning that will be traced in the political rhetoric of Joko Widodo examined in this article.

\section{METHOD}

Since the type of data to be sought in this research concerns empirical data that are used by one of the candidates in the 2019 presidential election, the method used to collect the data of this research was the documentation method. In this case, researchers look for data related to the use of language (political correctness) in various sources, especially through the media, online mainstream media, which was used by Indonesia presidential candidate number 01, Joko Widodo.

By using a descriptive-qualitative approach, elaborating the linguistic phenomena was not based on the quantity of language that appears, but based on aspects of the forms and meanings that arose. In this connection, the intralingual and extra lingual methods were used to analyze the data within this research [14]. Thus, researchers could find conversational implicature in political rhetoric used by Joko Widido throughout the 2019 presidential election campaign (check [15][16]).

\section{FINDINGS AND DISCUSSION}

Presidential candidate number 01, Joko Widodo, is the presidential candidate of the republic of Indonesia for the period 2019-2024 supported by nine Political Parties, namely Partai Persatuan Pembangunan Perjuanagan (PDIP), Partai Golongan Karya (Golkar), Partai Persatuan Pembanguan (PPP), Partai Kebangkitan Bangsa (PKB), partai Nasional Demokrat (Nasdem), Partai Solodaritas Indonesia (PSI), Partai Persatuan Indonesia (Perindo), Partai Keadilan dan Persatuan Indonesia (PKPI), and Parti Hati Nurani Rakyat (Hanura). Some of the parties that support the President JokowiAmin pair are parties that were previously a party supporting the government.

Presidential Candidate Joko Widodo (Jokowi) is actually known as having a calm personality. However, on several occasions, Jokowi made statements that were considered to be less than pleasing or inappropriate from the linguistics taste point of view of the Indonesian people. Some of Joko Widodo's statements that went viral are discussed below, one of which is his statement related to the politisi sontoloyo.

The meaning of the word sontoloyo in the Indonesian Dictionary is 'ridiculous, wrong, stupid (used as swear words)'. This word comes from the Javanese language which is used daily to express resentment or frustration towards others. This word was also conveyed by the First President of the Republic of Indonesia, Sukarno, who became the title of a book he composed himself entitled Islam Sontoloyo: Thoughts Around the Renewal of Islamic Thoughts, published by Basabasi. The use of the word sontoloyo again by Jokowi as the incumbent presidential candidate, in the context of the 2019 presidential election campaign, seemed to stomp the public because it was considered impolite, let alone delivered by someone who had been known for his calm personality.

Judging from the context, Joko Widodo revealed the statement during the distribution of land certificates to residents of Kebayoran Baru, Tuesday (10/23/208). At that time Joko Widodo conveyed the plan of the village fund program which became polemic and drew a lot of 
criticism, especially from the opposition. The village funds reached to 3 trillion which were taken from the 2019 APBN reaching IDR73 trillion. As quoted by many mainstream media, Jokowi said the following statement.

"Hati-hati, banyak politikus baik-baik, tapi banyak sekali politikus yang sontoloyo"1

Which literary means "Be careful, there are a lot of good politicians, but there are sontoloyo politicians as well.

On that occasion Jokowi conveyed the sontoloyo statement to criticize his political opponents who, according to him, take whatever means to carry out their political action. The all means referred to by Jokowi was the refusal of his political opponents to the plan to disburse the village funds which were planned to be disbursed in 2019. For Jokowi, those who prevent the disbursement of village funds were sontoloyo politicians. Furthermore, Jokowi said that the characteristics of the sontoloyo politicians are those who attack his political opponents without good manners.

Of course, the sontoloyo politician referred to by Jokowo was the politician from the opposition party. From this, it can be seen that Joko Widodo's statement implies that only his political opponents behaved in a foolish manner. This is where the violation of the "political correctness" can be seen, or in pragmatics referred to as a violation of the principle of politeness.

Like a political rhetoric, each camp in the 2019 presidential election interpreted the intentions of Jokowi's statement according to their interests. Those who supported Jokowi said that what Jokowi said was natural because President Soeakarno had also expressed the same thing by saying "Islam sontoloyo".

The opposition, in this case the chairman of the Patai Gerindra, Fadli Zon, said the president's statement was a rude statement, which is not appropriate for a president to say. Another response came from Gerindra Politician Andre Rosiade, who said that Joko Widodo's remarks were not appropriate and should not come from a president's mouth. Similarly, Democratic politician Ferdinand Hutahaean stated the same opinion as Andre and Fadli Zon.

At this point, it can be seen that a political statement or political rhetoric stated by presidential candidate Joko Wododo looks normal to his coalition, but for the opposition, it is an inappropriate form of speech. At this point, it is necessary to study the implications of the conversation to find out more whether there had been a surplus of meaning that had led to the desecration of the other candidate.

As has been explained earlier that, in general, the meaning of speech in a language has a predicature, especially in political language. In this case the sontoloyo statement stated by Joko Widodo, cannot be interpreted as an ordinary form of language, moreover Joko Widodo is a

${ }^{1}$ Published on kompas.com entitled "Jokowi: Hati-hati, Banyak Politikus Sontoloyo!",

https://nasional.kompas.com/read/2018/10/23/19303951/jokowi-hatihati-banyak-politikus-sontoloyo. Writer :Ihsanuddin, Editor : Sabrina Asril. figure who has been seen as having a calm disposition. The word sontoloyo that came out of Joko Widodo must be seen as a form of self-sufficiency or insults against political opponents, in this case the camp 02, which did not support the government's plan to take the village funds as much as 3 trillion taken from IDR73 trillion village funds in the State Budget.

So, has Joko Widodo ignored political correctness or not? If sontoloyo is interpreted in its most extreme meaning 'stupid', then Joko Widodo has ignored political correctness, or in pragmatics, Joko Widodo's statement has implications that lead to violations of the principle of politeness.

\section{CONCLUSION}

The term "political correctness" is a familiar phrase in the context of democracy in the west. However, in Indonesia, this term is yet to be that familiar, both in political studies and in language studies. However, because "political correctness" is usually part of political rhetoric, this rhetoric certainly cannot be separated from linguistic studies, in this case, pragmatics, especially those related to linguistic implications.

Furthermore, in the political rhetoric of Joko Widodo, in which he said "sontoloyo", cannot be separated from the implications of conversational implications because the statement does not have a single meaning. On the contrary, the meaning of the word sontoloyo, spoken by Joko Widodo in a very specific context, presupposes there has been an attempt to ignore "political correctness" or in this article is called "anti-political correctness".

However, this does not mean that in the 2019 presidential election, political opponents of Joko Widodo namely the camp 02 (or presidential candidate Prabowo Subianto) did not do the same thing. The limited space in this context caused the research team to limit only the rhetoric delivered by Joko Widodo.

\section{REFERENCES}

[1] J. Hopton, "The 'political correctness' debate and caring in psychiatric nursing," Nurse Educ. Today, vol. 15, no. 5, pp. 341-345, 1995

[2] L. Shafigullina and O. Shemshurenko, "Politically correct euphemisms in mass media (based on American and Turkish online periodicals of the beginning of the 21 st century)."

[3] A. Kurylo and J. S. Robles, "How should I respond to them? An emergent categorization of responses to interpersonally communicated stereotypes," J. Intercult. Commun. Res., vol. 44, no. 1, pp. 64-91, 2015.

[4] P. Wikström, "No one is "pro-politically correct': Positive construals of political correctness in Twitter conversations," Nord. J. English Stud., vol. 15, no. 2, pp. 159-170, 2016.

[5] R. S. Stade, "The Social Life of Fighting Words: The Case of Political Correctness," Confl. Soc., vol. 3, no. 1, pp. 108-124, 2017.

[6] M. Croce and A. Salvatore, "Normality as social semantics. Schmitt, Bourdieu and the politics of the normal," Eur. J. Soc. Theory, vol. 20, no. 2, pp. 275-291, 2017.

[7] J. Bylund, "Postpolitical correctness?," Plan. Theory, vol. 11, no. 3, pp. 319-327, 2012

[8] M. K. . Al-Rawi, "Theoretical analysis of Political Correctness Views," iJAR Int. J. Humanit. Soc. Stud., vol. 3, no. 2, 2017.

[9] I. Cepeda-Mayorga, "Political Correctness' from a 'Border Reason': Between Dignity and the Shadow of Exclusion," 
Philosophies, vol. 2, no. 2, p. 13, 2017.

[10] L. G. Conway, M. A. Repke, and S. C. Houck, "Donald Trump as a cultural revolt against perceived communication restriction: Priming political correctness norms causes more Trump support," 2017.

[11] В. М. Желтовський, "To Sell Military Campaign in Iraq Stressing the Freedom Theme: How Politically Correct Vocabulary Was Used by George W. Bush," Наукові записки [Національного університету Острозька академія]. Сер. Філологічна, по. 11, pp. 18-25, 2009.

[12] M. N. Konye, "Which theory of communication is 'political correctness'?," J. Educ. Cult. Soc., vol. 7, no. 2, pp. 53-74, 2016.

[13] I. Skoczeń, Implicatures within Legal Language. Springer, 2019.

[14] M. S. Mahsun, Metode Penelitian Bahasa: Tahapan Strategi, Metode dan Tekniknya. Jakarta: PT Raja Grafindo Persada, 2017.

[15] L. Cummings, Pragmatik: Sebuah prespektif Multidisipliner. Yogyakarta: Pustaka Pelajar, 1999.

[16] G. Yule, Pragmatik. Yogyakarta: Pustaka Pelajar, 2006 